\title{
Development of Problem-Based Learning Models to Increase Learning Outcomes in the Subtheme "My Residence"
}

\author{
Faidah Nur Imamah, Wahyu Sukartiningsih \\ Universitas Negeri Surabaya \\ Surabaya, Indonesia \\ Faidahnurimamah@gmail.com
}

\begin{abstract}
The purpose of developing learning tools by using problem-based learning model is to obtain a feasible, practical, and effective product. The development procedure uses Thiagarajan's 4-D (Four-D Model), Semmel \& Semmel (1974) model adopted from Ibrahim (2008). The development procedure consists of 3 stages: Define, Design, Development. The lessons developed include implementation of lesson plan, students' worksheet, students' teaching material, and learning outcome test. The finding indicates that the device was valid, with lesson plan validation $80.6 \%$, worksheet $78.4 \%$, BAS $80 \%$ and THB $79 \%$, thus, the validity of all learning devices reached $79.5 \%$, which falls to good criteria. In the test results, the control class reached $76 \%$ completeness, while the experimental class reached $90 \%$.
\end{abstract}

Keywords-Learning Tool, Problem Based Learning, My residence.

\section{INTRODUCTION}

Education aims to build people, characters, knowledge, and skills, so as able to produce healthy human and good character, pure knowledge, and skilled individual. Education is also one way to achieve progress and excellence to master science and technology. Act on National Education System [1] states that education plays the role of developing the ability and shape the character and civilization of a dignified nation in order to educate the nation, develop the potential of children to be a human being who believes and pious to God Almighty, noble, healthy, knowledgeable, capable, independent, creative and become a democratic and responsible citizen.

One of the government's efforts through the Ministry of Education and Culture is to improve the Education Unit Level Curriculum mindset to the Curriculum 2013, they are: (1) Changing teacher-centered learning patterns into studentcentered learning; (2) one-way learning pattern into interactive learning; (3) passive learning patterns into active-looking learning; (4) the learning patterns themselves become group learning (team-based); and (5) passive learning patterns become critical learning, with learning characteristics developing a balance of spiritual, social, curiosity, creative, cooperative, psychomotor, knowledge, and skill attitudes and applying them to various situations in schools and communities [2].

Students today live in a different world and are much more complex one than in the past. Educational teachers at school as a leading figure in the educational process is expected to provide knowledge, attitude, behavior, and skills through strategies and learning patterns in accordance with the demands and developments of the times.

[3] states that the scientific approach step embraces some aspects of achievement of learning outcomes contained in learning activities. Learning process touches three domains: attitude, knowledge, and skills. Learning outcomes produce productive, creative, innovative, and effective learners through observation of attitudes, skills, and integrated knowledge.

By learning by using the Curriculum 2013 through scientific and contextual approach in learning, students are expected to have a balanced competency between attitude, skill, and knowledge much better than before, in addition to the expected learning results give birth productive, creative, innovative, and effective learners through the strengthening of integrated attitudes, skills and knowledge.

Based on observations made by researchers at MI ALFITRAH Kenjeran Surabaya, teachers were not able to apply the scientific model and still follow the old pattern or the subject approach. The teaching and learning process was still carried out conventionally, learning was dominated by teaching material and the students only listen and record what is delivered by the teacher. Students can not actively play the role as directed by the 2013 curriculum such as observing, asking, trying, processing, tasting, reasoning and creating. Students do not understand the things that exist in the environment where they perform their daily activities.

The score obtained by fourth-grade students at MI ALFITRAH Kenjeran Surabaya showed that only 15 students from 31 students of grade IV A completed the material. This does not mean that teachers are not able to teach in the classroom and are not able to make good learning tools. Teachers have had learning tools but have not used problem- 
based learning method. Therefore, the researchers are interested to try to develop learning tools using Problem Based Learning method.

Problem Based Learning is designed based on living life problems that are ill-structured, open, and ambiguous [4] . Problem-based learning can generate students' interest, real and appropriate to build intellectual ability, and have the idea that learning can be achieved if educational activities are centered on authentic, relevant and presented tasks or problems in one context.

This learning model is based on the view of constructivism. Piaget assumes that in learning the knowledge is built by the child himself in cognitive learning through interaction with his environment. [5] Problem-Based Learning can also challenge the mind and nuance of the puzzle for learners so as to enhance the sense of cultivation, high activity and perseverance to always be involved in the teaching and learning process.

The authors expect an increase in student learning outcomes by developing the ability and creativity of students, especially in the subjects of Social Sciences with ProblemBased Learning method. Problem-Based Learning method is considered more effective, varied and innovative because the learning method can remind the involvement of learners and can foster creativity and independence in the learning process to obtain information, experience and gain new knowledge of the findings in the learning process undertaken.

Based on the description of the background, the researcher conducts research development using Problem Based Learning method with the title "Development of problem-based learning model to increase learning outcomes in the subtheme "My Residence".

\section{METHODS}

The development procedure uses Thiagarajan 4-D (Four-D Model), [7] design; (3) develop; (4) disseminate. The model of learning device development used in this study is as suggested by Thiagarajan, Semmel and Semmel (1974) adopted by [8] that's is $4 \mathrm{D}$ model (Four D Models) which is reduced to 3-D i.e Define, Design, Develop.

The development trial stage includes individual, limited, and field trials. In individuals, trials were conducted on 4 students. In limited development, trials were conducted on 10 students. In field trial of development, experiments on revised learning devices on one group or research subjects i.e. 31 students of grade IVA and 34 students of grade IVB.

The use of learning tools is done by using the research design "Pretest-Posttest Control Group Design." The data collection instruments used in this study are (1) Expert validation sheet to know the feasibility of learning tools according to the expert and questionnaire of student responses on individual and small group test to know the students 'responses and know the lack of learning tools' (2) Observation sheet of learning implementation to know the practicality of learning device, and (3) Test Sheet to know student learning result.

\section{RESULTS AND DISCUSSION}

\section{Feasibility}

Device feasibility was obtained through validation by Julianto, M.Pd and Dr., Dawn. M.Pd with recapitulation in Table 1.

TABLE I.

\begin{tabular}{lcc}
\hline & \multicolumn{2}{c}{ Recapitulation of Lesson Plan Validation } \\
\hline Average & Score & Information \\
\hline 3.2 & $80.6 \%$ & Good, can be used \\
\hline
\end{tabular}

TABLE II.

BAS Validation Recapitulation

\begin{tabular}{lcc}
\hline Average & Score & Information \\
\hline 3.2 & $80 \%$ & Good, can be used \\
\hline
\end{tabular}

TABLE III

Worksheet Recapitulation

\begin{tabular}{lll}
\hline Average & Score & Information \\
\hline 3.1 & $78.4 \%$ & Good, can be used \\
\hline \multicolumn{3}{c}{ TABLE IV. } \\
\hline \multicolumn{3}{c}{ THB Recapitulation } \\
\hline Average & Score & Information \\
\hline 3.1 & $79 \%$ & Good, can be used \\
\hline
\end{tabular}

Based on the table above, the assessment of learning device validation results is 'Good' or usable. The worksheet developed by scientific approach is worksheet which is adapted to the components of the scientific approach, i.e. observing, asking, gathering information, processing information and communicating the results [9].

Having been declared Good, the worksheet is used in individual and small group trials. The purpose of this trial is to evaluate (a) the suitability of the material and the ease of study (b) the suitability of competence with the task in learning (c) what the presentation format is interesting to learn. Trial is done by giving LKS to the students. Students are required to fill in the provided questionnaire. This trial process is open, so during the experiment researchers invite students to interact to get the shortage of LKS that have been developed. 
Individual trials were conducted on April 3, 2017 at MI Ihyaul Ulum students with $78 \%$ having good criteria. Small group trials were conducted on Tuesday, April 10, 2017 on MI Ihyaul Ulum students and $88 \%$ had very good criteria. Field trials resulted in 93\% percentage made on April 18, 2017.

\section{Practicality}

The learning of the 2013 curriculum is a meaningful learning in accordance with the scientific approach. Studentcentered learning and teachers act as facilitators and motivators in learning.

\section{Table 5}

Recapitulation of the Implementation of Learning Learning I Percentage

and II

\begin{tabular}{lll}
\hline & 3.8 & $91.8 \%$ \\
Note & Implemented well & \\
\hline
\end{tabular}

\section{Effectiveness}

The development of learning tools is effective by looking at the comparison of the students' learning outcomes in the experimental class, i.e. the class using Problem-based learning and control class, which is a class that uses learning tools that are readily available from publishers commonly used by the school. Through pretest results, the two classes were statistically analyzed for normality and homogeneity test. Normality test aims to determine whether in each class is normally distributed or not. If $\chi 2$ count $\geq \chi 2$ tables, data distribution is not normal, if $\chi 2$ count $\leq \chi 2$ tables, data distribution is normal [10].

Based on result of normality test of experiment class posttest value, $\chi 2$ count is 5.71 and $\chi 2$ tabel that is 11.070 at significance level 0.05 and 9.2365 at significance level 0.01 . If $\chi 2$ count $\leq \chi 2$ tables, the normal data distribution is $11.070>$ $5.71<9.2365$. So it can be concluded that the posttest grade of the experimental class is normally distributed. While the value of posttest control class obtained $\chi 2$ count $=8.27$ and $\chi 2$ tables 0.05 i.e. 12.82 at the level of significance of 0.05 and 10.812 at the level of significance 0.01 so that $12.82>8.27$ $<10.812$. So it can be concluded that posttest value of the control class is normally distributed.

In homogeneity test, if $\mathrm{F}$ count $<\mathrm{F}$ table, homogeneous variant and the data analysis is $0.93<1.79$, then the data is homogeneous for pretest data and the posttest data $1.43<1.79$, which is also homogeneous.

In Test $\mathrm{T} t$ arithmetic posttest is $3.77885>1.670$. This shows that $\mathrm{t}$ count is greater than $\mathrm{t}$ table. Thus there is a difference in learning outcomes between the experimental class and the control class. Posttest results on field trials improved significantly.

In conclusion, student learning outcomes have increased significantly after using the learning tool of Problem Based Learning model.

\section{CONCLUSION}

1. Based on the validation result from the validator, the average score of the overall is 3.2 for lesson plan, 3.2 for BAS, 3.2 for worksheet and 3.1 for THB. The learning device developed is valid and feasible to use.

2. Based on the analysis, observation data include:

a. Students' activity during the learning process, categorized 'very good' with an average of $93 \%$.

b. b. An average percentage of $91.8 \%$ for implementation falls in 'very good' category. The learning device developed is practical to use.

3. There are differences in learning outcomes between student groups taught using problem-based learning tools with groups taught using conventional learning.

The average score is 82.3 and 78.1 on experimental class and control class, respectively. Thus, learning in experimental class was able to improve student learning outcomes than in the control class.

\section{REFERENCES}

[1] U.-U. S. P. Nasional, "Nomor 20 Tahun 2003," Bab I Pasal, vol. 1.

[2] R. Permendikbud, "Nomor 65 Tahun 2013," Lampiran Peraturan Menteri Pendidikan dan Kebudayaan Republik Indonesia Nomor 69 Tahun 2013 tentang Struktur Kurikulum SMA-MA.

[3] M. Hosnan, Pendekatan saintifik dan kontekstual dalam pembelajaran abad 21: Kunci sukses implementasi kurikulum 2013: Ghalia Indonesia, 2014.

[4] J. Guy, B. J. Hindman, K. Z. Baker, C. O. Borel, M. Maktabi, N. Ostapkovich, et al., "Comparison of remifentanil and fentanyl in patients undergoing craniotomy for supratentorial space-occupying lesions," Anesthesiology: The Journal of the American Society of Anesthesiologists, vol. 86, pp. 514-524, 1997.

[5] L.-F. Lin, "The impact of problem-based learning on Chinesespeaking elementary school students' English vocabulary learning and use," System, vol. 55, pp. 30-42, 2015.

[6] Drake and D. Long, "Rebbecas In The Dark A Comparative Study Of Problem-Based-Learning And Duect Intruction/Eksperiential Learning In Two 4th-Grade Classrooms," Jurnal Of Elementary Science Education, vol. 21, pp. 1-16, 2009.

[7] S. S. Thiagarajan, "DS \& Semmel, MI.(1974)," Instructional Development for Training Teachers of Exceptional Children.

[8] M. Golparvar-Fard, S. Savarese, and F. Peña-Mora, "Automated model-based recognition of progress using daily construction photographs and IFC-based 4D models," in Construction Research Congress 2010: Innovation for Reshaping Construction Practice, 2010, pp. 51-60.

[9] P. M. Pendidikan, "Kebudayaan (Permendikbud). 2013," Standar Proses Pendidikan Dasar dan Menengah. Jakarta: Permendikbud.

[10] M. Riduwan, "Belajar Mudah Penelitian Untuk Guru-Karyawan dan Peneliti Pemula," Bandung: Alfabeta, 2006. 